\title{
Teaching economics in a changing South African environment
}

\author{
W.H. Thomas and Elti Links \\ Department of Economics, University of the Western Cape, Bellville
}

This short, exploratory paper hopes to trigger further debate, research and other relevant action with regard to teaching economics in a changing South African environment. It is argued that the challenges confronting university teachers of under-graduate economics and the teaching of economics in secondary schools are many and diverse. Not least is the need to add to the teaching of general principles, the teaching of the actual functioning of the South African economy. The authors also consider curriculum development, teaching material, the training of teachers, university-technikon links and adult and nonformal education.

S. Afr. J. Bus. Mgmt. 1986, 17: $108-116$

Hierdie kort, eksploratiewe artikel is geskryf met die oog om verdere debat, navorsing en ander toepaslike aksies te ontlok ten opsigte van die onderrig van ekonomie in 'n veranderende Suid-Afrikaanse omgewing. Daar word toegegee dat die uitdagings waarmee universitêre leerkragte en onderwysers in sekondêre skole gekonfronteer word baie en uiteenlopend is. Dit is egter nie genoeg om algemene beginsels te doseer nie, onderrig in die werklike funksionering van die Suid-Afrikaanse ekonomie is ook nodig. Die sknwers oorweeg ook veranderinge aan die curriculum, onderrigmateriaal, die onderrig van leerkragte, universiteittechnikon kontak en selfs nie-formele volwasse opvoeding. S.Afr. Tydskr. Bedryfsl. 1986, 17: $108-116$

Paper presented at the Conference on Management and Economic Sciences, Cape Town, 29 October 1985

W.H. Thomas and Elti Links

Department of Economics, University of the Western Cape,

Bellville, 7530, Republic of South Africa
What does it mean 'to think like an economist'?

I would like it to mean:

(i) realizing that it is possible to think rigorously about social problems;

(ii) understanding the interplay of facts, values and theories in economics and in knowledge generally;

(iii) knowing how to evaluate the cogency of an argument in economics, to keep from being snowed;

(iv) having some sense of our economic institutions;

(v) having thought through at least one or two policy issues in a serious way.

- Robert Solow

\section{Introduction}

The subject matter of economics is taught and studied at different levels, each of which has for some time been experiencing rapidly rising student numbers. In general, we can distinguish dissemination of knowledge about the subject of economics at three different levels, viz. university and other tertiary level institutions, high schools, and non-formal education programmes. Roughly about $10 \%$ of the 200000 students enrolled in South African Universities register for one or more courses in economics. At high schools (Std. 8-10) economics has during the past 10 years spread rapidly amongst schools, reaching well beyond the traditional 'commercial streams', and enrolment for matric has increased substantially, both at white and black schools. In addition to these two main fields of teaching/studying economics, the demand for 'some' economic subject matter in commercially, managerially and even technically orientated correspondence and/or adult education programmes has also increased sharply. Finally, 'economic issues' as causes underlying present socio-political changes and conflicts or as elements of reform strategies also figure increasingly in public debate.

Against this background it is remarkable and disconcerting at the same time that virtually no attention seems to be given to the challenges and problems related to this rising demand at least as far as one can judge from the published literature in South Africa' (Eksteen, 1975; Burger, 1987a: 194 - 197; 1978b: 231 -234). Neither have the Economic Society of South Africa ${ }^{2}$ (Zarenda \& Rees, 1984: 188 - 207; Botha, 1973:281 - 290) or the annual Lecturers' Development Programmes given any serious attention to this field ${ }^{3}$ (Robbins, 1955: 579-593; Siegfried \& Fels, 1979: 923 -939), nor does one see concrete signs of such steps at the level of school educators, whilst the correspondence course 'market' for material on economics has for years subsisted on meagre diets of overseas texts with little locally relevant support material. 
The situation becomes all the more disquieting if one places the expanding 'demand' for study material within the fundamentally and rapidly changing framework within which South Africa's students of the 1980 s are perceiving 'economic reality'. Whilst most of our teaching material, curricula and teachers' approaches barely satisfy the demands for the teaching of our subject within the constraints of a 'capitalist market economy' or 'mixed economy' orientation, a new generation of students is coming forward at our schools, and will no doubt soon reach universities and other training programmes, who either totally reject the capitalist basis of our teaching or, at the very least, demand a more balanced or multi-faceted approach ${ }^{4}$ (Sherman, 1984: 265 - 274). The vehemence with which high school student leaders have rejected South Africa's contemporary socio-economic system should be enough to raise our concern and get us out of the lethargy of merely reproducing conventional wisdom.

In North American academic life such critical views on 'The Teaching of Economics' have a long and well-established tradition, as can be deduced from the annual Papers and Proceedings of the American Economic Association. To illustrate this approach we can quote at some length from a paper presented in 1969 by a group of the 'staff of Social Sciences 125' at Harvard, entitled 'A Radical Approach to Economics: Basis for a new Curriculum' (AEA Papers, 1970: 352);

'The purpose of this paper is to outline a radical approach to economics and to suggest how several important social problems might be dealt with in that framework. Our effort to develop a new curriculum is motivated by the conviction that the orthodox approach to economics cannot deal with the important problems of modern society.

Orthodox economic analysis as presented from the elementary course through the graduate seminar is based upon an acceptance of the status quo in social relations. Microanalysis presupposes the individualistic ownership and decision-making systems typical of capitalist societies, and in this narrow context the pecuniary behavior of firms and individuals is examined. In macroanalysis, when the aggregate operations of these individual units are the subject matter, attention is focused on the fiscal and monetary adjustments necessary to keep the system smoothly functioning. All in all, the curriculum of modern economics is one of philosophic marginalism: existing social relations are taken as a datum and the problem is one of administering the system by adjustments around the edges.

The marginalist approach is useful only if, accepting the basic institutions of capitalism, one is primarily concerned with its administration. If one questions the virtue of capitalism as a system, then the basic social relations and the institutions of the system themselves must be subjected to analysis. A new approach is necessary.

The old approach - that which accepts capitalism and is in general the basis of present economics curricula - cannot deal with the problems of modern society. All that the curricula say about the war in Vietnam is how it can be financed more efficiently. The very existence of imperialism is denied. Racism, it is taught, has its origins in personal preferences, and the poverty of blacks and others is "explained" in terms of their low productivity. The destruction of the environment enters the curricula only as an aside when the existence of "externalities" is pointed out as limiting the theory.
The subjugation of women, the meaninglessness of work activities, and the alienation of workers are topics which do not enter the curricula at all. Socialist alternatives and the process of revolution are examined only in terms of the value system of a capitalist environment. It is our contention that such issues - their historical existence, causes, dynamics, and consequences - should be central to a new economics curriculum. This curriculum would reflect the motif of modern American capitalism: conflict and power. Attention would be focused upon the basic economic institutions of capitalism and the class divisions which those institutions foster.'

In as far as the ready availability of a wide range of overseas study material (including textbooks) might have been a legitimate excuse in the past for not getting more involved in the production of locally adapted material, the cost explosion with respect to important material no longer provides this alibi. The exchange rate is unlikely to improve and books may soon be added to those important categories where the support of local production will lead to further tariffs or controls.

It should be clear from the above that this short article cannot do justice to all the challenges arising out of this changing situation. It should be regarded as exploratory only, with the underlying hope that it will trigger off further debate, research and other relevant action. It might also lead to a greater awareness of research and experimentation already in process in these fields, though not yet known to all of us.

To conclude this introduction, brief mention can be made of a research project recently initiated at UWC's Department of Economics under the title STEEP (Secondary and Tertiary Economics Education Project) ${ }^{5}$ (Links \& Thomas, 1985). With only limited initial funding and without any pretense of tackling the full spectrum of issues related to the teaching of economics, the following aspects are currently addressed:

- the adjustment of a popular UK introductory text (Lobley, 1983) to meet the requirements of South Africa's technikon level students in economics;

- preparation of PLATO-based question and revision sets;

- compilation of empirical and institutional supplementary study material for secondary and tertiary level students;

- communication with secondary and tertiary level staff about the need for in-service training programmes and other needs ${ }^{6}$.

Hopefully, these initiatives will lead towards more effective cooperation between the relevant departments of the education and commerce faculties at UWC, resulting (i.a.) in joint masters research and training programmes. In addition, it might lead to coordinated action amongst relevant institutions in the Greater Cape Town area, or even the Cape Province. Aside from this, research links with similar attempts at universities, technikons or secondary level educational institutions elsewhere in the country would, of course, also be welcome.

In the remainder of this article the focus will fall primarily on two levels, viz. undergraduate economics and the teaching of economics at secondary schools. Only brief reference will be made to graduate level economics and adult or non-formal education, even though both these areas deserve far more attention.

\section{Undergraduate teaching of economics}

Task and challenge

The challenges confronting university teachers of undergraduate economics in the post-1985 Southern Africa come from five different directions:

- the demand for 'relevance' and critical orientation, vis-á-vis 
the rapidly changing Southern African political economy;

- the demand for reasonable standards and teaching methods, given the changing composition of the student body and the increasing need for direct or indirect "academic support ${ }^{7}$ orientations;

- the demand for practical knowledge relevant to job market needs and preferences ${ }^{8}$;

- the demands arising out of the virtual explosion in student numbers at undergraduate (first/second year) level, with relatively slower increases in staff contingents ${ }^{9}$; and

- the direct or indirect 'competition' of technikons.

This diversity of challenges suggests that no simple 'reform' or reorientation will be able to do justice to the complex task of undergraduate teaching in a broad-based subject like economics $^{10}$ (Lumsden, 1970; Lumsden, Attiyeh \& Scott, 1980; Roper, 1970; Livingstone, 1973). In fact, the above list could easily be lengthened, e.g. by referring to the rapid world-wide expansion in the academic subject matter of economics and its increasing quantification, both of which trends would seem to demand greater specialization even at undergraduate level ${ }^{11}$ (Botha, 1981 and 1985 - see the comments on 'Graduate teaching of economics'). However, in this section we shall limit our attention to a few areas where the need for rethinking seems most urgent. They are related to the above five challenges, but will not be discussed in the same sequence. Some of them will, in fact, not be considered here at all.

\section{Curriculum development}

In contrast with school curricula development relatively little attention is usually given to the particular content and gradual adjustment of (economics) curricula at university undergraduate level ${ }^{12}$ (Hummel, 1984). Long-established conventions, imitation of the 'leading' universities, strong personal preferences of staff members or heads of departments, curricula implicit in the standard overseas texts used in South Africa, and the natural inertia to pursue innovative approaches all contribute to the maintenance of the status quo - albeit with a few stylistic adjustments each year.

By questioning the status quo we do not suggest any specific alternative, but rather want to highlight the absence of any more concerted inter-university efforts at curriculum reassessment, reorientation and possible reform. Naturally, such efforts should not ignore the rather disappointing results of 'alternative texts' on the international market ${ }^{13}$ (Robinson \& Eatwell, 1973; Aboyade, 1983; Routh, 1984) and possibly even some of the more individualistic local reform attempts. Yet, disillusionment at the outset does not preclude a serious process of soul searching and communication - incorporating all those concerned with the teaching of the subject, as well as those affected by the outcome of all teaching efforts.

Such reassessment might, amongst others, give attention to the following possible shortcomings of contemporary undergraduate curricula:

(i) Sufficient consideration is not given to the fact that many students drop the subject already after the first year, and most have dropped it after the second year. Often crucial, more applied aspects of the subject matter are left for 'later years' when all the 'prerequisites' have been 'mastered', conveniently forgetting that the bulk of the students never reach that stage. Alternatively, the practice at some universities, of offering separate course streams, including one year 'political economy' or applied economics courses, might also be expanded.

(ii) Factual overviews of the current stark economic realities of South(em) Africa are largely neglected in "principles courses', where the emphasis usually falls on concepts, definitions, analytical tools, and models. The need for the latter can, of course, not be denied and it will always have to take up the greater part of the curriculum, but at the same time one dare not overlook the fact that real life economic issues are highly relevant to all of us, including those studying the subject. By merely sticking to outdated, often highly stylized 'model examples' we cannot satisfy that urge, but may actually push the academic subject right outside the spectrum of took regarded as 'relevant' by students.

(iii) During the first two years of university study in economics too little attention is given to alternative sociopolitical frameworks for the organization of economic activities. In the South African context this should include serious consideration of the principles upheld by supporters of UDF, ANC and other left-of centre ideologies, as well as models supported widely in Third World and semi-developed countries of Latin America, Africa and Asia. To seriously analyse and study these alternatives does not imply either tacit or active support of them; but it does imply an open mind towards challenging views.

(iv) In addition to general principles of economics the first two years should give more attention to the actual functioning of the South African economy, in particular

- an awareness of key magnitudes and empirical relationships necessary to interpret day-to-day economic reporting and changing trends;

- sensitivity for institutional structures underlying the functioning of markets and other key elements in the economy; and

- sectoral development patterns viewed in historical as well as comparative (international) perspective.

(v) Whilst it is doubtful that more lecturing space can and should be made available for formal economic history in economics courses ${ }^{14}$, in presenting most subdisciplines of economics - like labour, development, international trade, imperfect competition, banking, regional/urban economics, etc. - a distinct historical perspective could be useful, and should be incorporated. It seems quite wrong and unnecessary to make historical perspectives the sole prerogative of marxist-orientated courses or modules.

(vi) The artificial segmentation between First World-orientated 'mainstream' economics and 'development economics' (with more or less South African nomenclature) should be overcome, given the close interaction if not tight mixture of these strains in the South African political economy.

(vii) During (or towards the end of) the first two years more specific attention needs to be given to the interaction of all the major areas of economic policies and economic intervention, seen against the background of alternative socio-economic systems and changing societal goals.

(viii) In general, more attention has to be given to the integration of often fragmented subdisciplines or modules.

(ix) In order to give more attention to the applied dimension of subdisciplines - and to consider those issues in their broader historical and socio-economic perspectives more scope may have to be given to module options rather than the coverage of the full spectrum of sub disciplines in second/third year programmes.

(x) In line with the experience in other countries, consideration may be given to a further reduction in the range of 
subjects prescribed for the B.Com/B.Econ. or the introduction of 'economics (specialization)' degree programmes. The latter option may be the only way to reconcile the divergent goals of preparing for subjectspecific graduate studies (in the RSA or overseas) and preparing for an all-round insight and understanding, as well as the ability to use basic analytical tools effectively.

It might perhaps be an appropriate starting point for such a process of reassessment, to conduct a survey of economics curricula at South(ern) African tertiary education institutions.

\section{Teaching material}

Given the limited impact of even the best lecturing, the selection and use of relevant and suitable teaching material cannot be underrated. Yet, here again much of the choice still seems to be of the trial-and-error type, with more or less shrewed marketing efforts of publishers playing a key role. Unfortunately, most of those publications have been prepared for overseas markets, whereas the local supply of teaching material is extremely limited.

From the challenges and needs mentioned above 'appropriate' teaching material for the local market should include: - texts less voluminous than the 'normal' US 700-900 page omnibus volumes and more directly relevant to Southern Africa

- books partially or wholly translated into both official languages ${ }^{15}$ (Schumann, Franzsen \& de Kock; Lombard, Stadler \& Haasbroek, 1985; Stapelberg \& Steyn, 1983)

- books affordable to students (i.e. below \pm R25-30)

- books/supplementary material containing locally relevant empirical, institutional and historical material

- self-assessment testing/revision material appropriate for local students.

Critical perusal of booklength introductory economics material prepared for the South African market during recent years - like those by Nattrass (1981), ${ }^{16}$ Kantor \& Rees (1982), Lombard, Stadler \& Haasbroek (1985), ${ }^{15}$ Matthews (1983), Coleman (1983) and Nedbank (1983) - not only reveals the scarcity of such material but also its shortcomings and onesidedness. In contrast, more specialized texts or collections like those by McCarthy (1983) and Goedhuys (1982) on money and banking, Franzsen (1984) on public finance and Griffiths \& Jones (1980), Sadie (1980) and others on labour go further in meeting local needs but are even rarer in appearance ${ }^{17}$ (Matthews; du Plessis; Terreblanche).

Publishers specializing in university material seem to be aware of this dilemma, but feel caught between the lack of suitable script and market constraints. Language dualism, ideological biases and differences in minimum standards add to the market fragmentation.

There seems to be no easy way out of this dilemma. As a minimum, active and serious communication between tertiary level teaching departments will have to be initiated concerning specific needs, the availability of appropriate material, the production of new material and, hopefully in conjunction with some publishers, lowest-cost methods of reproduction and distribution. In all of this particular attention should be given to the problems faced by the smaller (black) university campuses and other tertiary training institutions, whose staff is usually least equipped to handle these problems ${ }^{18}$.

\section{Training of university teachers}

The accusation that university lecturers are the poorest trained teachers in the whole teaching profession is well-known and probably applies as much to the subject of economics as to others in the social sciences. Besides, the close interaction between theory, practice, ideology and socio-political conflicts puts even greater demands on teachers of tertiary level economics than on those of various other subjects. The fact that student numbers are increasing fairly rapidly further adds to the difficulty of meeting these demands.

At this stage there seems to be no written material specifically addressing the task of training university lecturers in economics $^{19}$ (Lumsden, 1970; AEA, 1985: 80-96; Bach \& Kelley, 1984: $12-18$ ). What is more, it seems doubtful that any of the past few years' 'lecturer development conferences' actually addressed this problem at all. Individual departments may be active in this field, but none of this seems to transcend towards other universities. Possibly, the following aspects could be considered:

(i) exchange of multiple choice (test bank) questions;

(ii) exchange of opinions/experiences about foreign/local texts;

(iii) sharing of supplementary empirical, institutional, historical or case study material (e.g. in the form of duplicated 'notes');

(iv) exchange of locally prepared study guides;

(v) exchange of exam/essay questions;

(vi) preparation (and exchange) of staff training manuals;

(vii) exchange of marking/grading experiences;

(viii) joint staff training seminars (on a regional/country-wide basis);

(ix) staff exchange programmes, either within a metropolitan area or region, or across the country;

(x) joint invitations to and use of foreign scholars experienced in staff training programmes (and sensitive to our type of student environment);

(xi) arrangement of joint student-staff seminars or workshops focusing on teaching approaches in economics;

(xii) assessment of subject training in the light of job market demands

(xiii) analysis of obstacles faced by women interested in this profession.

If the Economic Society of South Africa would be a genuine 'professional organization' some of these tasks might fall within the sphere of its responsibilities. In fact we would argue that a professional organization like the SA Economic Society should have as one of its primary objectives the fostering and development of economists, which calls for a direct involvement in the teaching of economics at not only university but even high school level. Naturally the $S A J E$ could also play a role in the process. At this stage no signs of such an involvement are evident, so that the challenge might in the interim be taken up by individual staff members or departments.

\section{University-technikon links}

In South Africa the relationship between universities and technikons ${ }^{20}$ has traditionally been an uneasy one, with the science of economics no exception ${ }^{21}$. Even the recent upgrading of technikons has not fully bridged the gap, although both types of institutions are probably by now fully aware of the fact that government and many employers no longer give universities a preferential ranking.

Student numbers at technikons have also increased rapidly, and would probably even have increased faster, had their facilities expanded sufficiently. As a result, some technikons nowadays practise more stringent screening of new applicants than universities ${ }^{22}$. If, in those cases the 'end products' of technikons are still not 'on par' with university graduates, the reasons relate to curricula and staff rather than students. 
Possibly these areas - curriculum development and staff training - also constitute the two fields where interaction between universities and technikons could be most fruitful possibly for both sides. Another important area relates to the preparation and dissemination of teaching material appropriate for South(ern) African students ${ }^{23}$ (see Teaching material above) and the mutual recognition of credits.

\section{Graduate teaching of economics: Some comments}

Graduate level training here refers to Honours and (Course) Masters study in the field of economics (for the Hons./ M. Comm., Econ., Admin., Soc.Science or Arts degree). Within the limited scope of this article no attention can be given to the broader issues of 'graduate level training - for what', i.e. whether students are, or should be trained for the local or the overseas job market ${ }^{24}$. Against the background of earlier sections of this article only a few issues can be raised:

(i) Honours courses (modules) should give enough scope to topics directly relevant to South(ern) Africa's current socio-economic and economic-structural transformation.

(ii) The ability of Honours students to grasp the realities of the local/international economy - empirically, institutionally and historically - can easily be overrated. In our presentation of graduate material this weakness should be overcome.

(iii) Whilst the strong emphasis on advanced micro/macro and quantitative skills is understandable at overseas graduate level studies, we should not merely imitate what is basically a weeding-out mechanism. In addition to getting understanding and insights, our graduate students should learn skills which they can apply once they are out in professional jobs - which may be soon after their graduate studies.

(iv) In the setting of topics for Honours and Masters (mini) dissertations we should not unduly follow contemporary overseas fads or limit ourselves to the classical fields of monetary, fiscal, trade and employment issues. Contemporary South Africa's economy is full of unresolved problems, with only a very limited number of people in an explicit problem-researching or problem-solving state of mind. Whilst the supervision of 'novel' or very applied topics may be harder, the pay-off could be higher as well, both to the individual and the country ${ }^{25}$

(v) Graduate students should be encouraged to grapple in module essays, class discussions or research papers - with the ideological issues increasingly confronting South Africa. To widen the scope of such exchanges inter-university links should also be used.

(vi) Masters students should be encouraged to further research issues related to the teaching of economics, both at secondary and tertiary level. With respect to course work, we are currently considering the introduction (at UWC, starting 1986) of some Honours/course Masters modules in this field. For example, the following fivecourse combination might result in an Economics Honours with an educational orientation:

1. Economics of education

2. Innovative teaching of economics

3. An applied research module (e.g. in curriculum and teaching material development)

4/5. Two modules from the standard range (e.g. micro/ macro/public finance/international economics)

Ideally, some arrangement would be entered with the education faculty to allow their UED/B.Ed. students to attend and gain credit with such modules (1,2 and/or 3).
We can conclude these few suggestions with a practical proposal that should be easy to implement:

- all departments offering Honours and course Masters programmes should exchange lists of the modules offered each year (and, possibly, also the names of the module convenors); and

- we should make another attempt at annually exchanging titles, student/supervisor names, and broad outlines of ongoing Masters/Ph.D dissertation research ${ }^{26}$.

\section{Universities and the teaching of economics at school}

The interaction between universities and secondary education authorities is close, divergent and complex - and this also seems to apply to a subject like economics which in the South African school scene is of fairly recent origin. On the one extreme we find some academics arguing that this subject should not be offered in school at $\mathrm{all}^{2}$, whereas the actual training of secondary school teachers for subjects like economics and the production of school texts by university staff constitutes the other extreme. Whilst there seems little need - nor justification, in the light of the more general remarks made earlier about South Africa's current educational revolution - to further consider the arguments by Rees and Zarenda, we can concentrate here on a few areas where the interaction is - or should be - fairly close $^{27}$ (Lee, 1980; Henderson, 1980; Burkhardt, 1976 and Bach, 1961:579-586).

\section{Cooperation at subject-advisory level}

If one regards the subject advisors, subject inspectors and related committees as the highest levels of decision-making about course curricula, prescribed literature, examinations, and the overall approach to the subject, effective participation of university representatives at this level seems essential. With respect to economics the system may or may not function effectively in the various provinces (for white education) and in the other ethnic education systems. As far as our experience is concerned - in Transkei during the period 1980 - 1982 and in 'Coloured education' since 1983 - the cooperation is not always successful. In the latter case the Subject-Advisory Committee was not convened once in 1984/85 and no attempt at all was made to establish contact with individual academics invited to be members.

Would it be asking too much if one expects - in the de Lange era of educational reform - that broadly based subject advisory committees spanning all educational authorities and a wide cross-section of university academics give in-depth and critical consideration to the present state of economics teaching at South(ern) African schools? Or will we wait with such steps until after the bulk of our (black) students have irreversibly rejected present teaching programmes as irrelevant or 'gutter education'? The criticism relates to syllabi as much as to teaching material, examination questions and teaching methods ${ }^{28}$ (Weekend Argus, 1985:9).

\section{Curriculum development}

Even before the recent outburst of pupil criticisms against outdated 'Apartheid syllabi' for school subjects - with economics prominently amongst those mentioned - the conventional Std. 8-10 school syllabus had for a long time been in need of rather drastic revision. To mention only a few points:

- The Std. 8 syllabus abounds with uninteresting conceptual clarifications, 'basic principles' and relatively unimportant topics.

- Economic history typically 'starts' with the arrival of whites 
and is, on the whole, as white ethno-centric as most of the old-style history books in South Africa.

- The emphasis all through Std. 8-10 is on factual memorization rather than the understanding of forces, developments, interactions, conflicts, changes, and trends.

- At no stage are pupils encouraged to investigate 'economic reality' around themselves critically in its sharp contrasts (rich/poor, rural/urban, employed/unemployed, owner/ rentier, investor/loanee, etc.)

- Nowhere in the syllabus are students helped to understand day-to-day economic reporting in newspapers, financial journals and other sources.

- Sectoral and other policy reviews in Std. 10 are largely uncritical vis-á-vis government policies. (Cf., for example, decentralization and influx control)

- At no stage is South Africa's position as higher level 'Semideveloped' country clarified, nor are relevant parallels drawn to other semi-developed countries. As a result, white pupils are encouraged to perceive 'their economy' as First World, looking down on the black segment as un(der) developed and vice versa.

- The capitalist, 'free market' approach is generally taken as 'the' (only) basis for the South African economy.

These are only a few more general points of criticism. Closer perusal of the syllabi - and the standard texts, which (far too) closely follow these syllabi - reveal a myriad of objectionable points ${ }^{29}$. In fact, going through the material one feels very tempted to start working on a totally different 'alternative programme', much like it has been attempted in subjects like mathematics, certain foreign languages, and history.

It is not clear whether our educational authorities are already prepared to allow such more fundamental reconsideration of the economics curricula. As long as this is still unsure one would at least hope that universities, by way of research and/or experimentation, will start work in that direction. Is anything happening already? Who would be prepared to participate? What lessons can we learn from elsewhere in Africa, in the Third World, or in western countries?

\section{Teaching material}

For more than a decade the three school economics texts by Swanepoel \& Stassen ${ }^{30}$ have dominated the literature available and/or used in the Cape Province/Transkei - and possibly even beyond these boundaries. Few texts could be less imaginative, more formalistic, less uncritical of the white-centred status quo and more in need of supplementary didactic material than this set. Even a cursory look at the Std. 8 text's introductory chapters makes one wonder why students pursue this topic - or how those 'trapped' in their choice (which often is no choice at all) could possibly perform well. Definitions, 'dry' facts, abstract relationships - and not even a glimpse of the real-life buzzle of 'an economy' or 'our' economic life in South Africa.

Leaving aside the indisputable need to gradually create a whole new type of school economics texts (the parameters of which first have to be explored and spelt out), there is an even more urgent need - in particular in the interim phase - for supplementary (illustrative) material on the South African economy. In addition, teachers need support material to enable them to convey the subject matter in a more interesting, imagination capturing and applied way. Finally, both students and teachers need access to revision and test question data banks.

The whole issue of adjusting conventional examinations and ongoing assessments also needs investigation, but falls outside the scope of this article. Nowhere does the appalling state of the high school curriculum present itself more vividly than in the examination questions set for matriculants.

It is rather ironic that many teachers of economics seem to be unable or unmotivated to use the wealth of illustrative material available everyday and week in the 'Business sections' of our newspapers and in the weekly journals ${ }^{31}$. Publishers of these papers/journals could, of course, also try more effectively to 'capture' this market, e.g. by including material more closely aimed at pupils and undergraduate students. If as serious a paper as 'The Economist' can include 'school briefs', why can't our papers do something about this? It might be fascinating, for example, to see how the $\mathrm{Fi}$ nancial Mail might try to get the message about 'Free Enterprise Capitalism' across to black matriculants studying economics.

\section{Teacher training}

Here we can distinguish two aspects, viz. training of secondary school teachers for economics and in-service training of teachers. In both spheres universities (should) play a central role and with respect to both the present situation seems unsatisfactory - certainly in the educational systems more closely related to UWC

With respect to the training of secondary school teachers for economics a few key issues should be considered:

- whether economics departments should be more involved in the offering of subject didactics;

- how students can be better prepared for the ideological issues likely to confront them at school;

- that students' didactics courses should be less narrowly confined to present syllabi, giving more scope to independent approaches and the (possible future) change of syllabi;

- how students/teachers can use published material on the economy readily available in newspapers and financial/ economic journals.

The field of in-service training for economics teachers still seems to be largely barren, even though the need may be quite critical at this point of time. In particular we are concerned about the link between the formal, theoretical or model-type approaches at university and the issues arising in the world surrounding the teacher and his pupils. If the teacher has recourse to only the formal style, the shortcomings of the status quo in disseminating knowledge is merely perpetrated.

However, it seems futile to come forward with specific suggestions, when even the nature, frequency and parties involved in such training are still unclear. About the need to involve university staff - in as far as they are responsive there should, however, be little doubt. Equally clear should be the fact that 'in-service training' includes various aspects, including, for example, regular feed-back workshops or weekly seminars for newly graduated/employed teachers. Otherwise it seems no wonder if even young teachers fall into the trap of 'conventional teaching' soon after they have started their jobs.

Ideally, such in-service training/contact programmes could constitute the planning ground for the coordinated preparation of supplementary teaching material.

\section{Adult education and non-formal education: Some comments}

From the discussion in previous sections it should be clear that undergraduate teaching of economics at university and 
secondary education in economics constitute two major challenges for university staff involvement. In a third area, that of less formal programmes falling within the wider spectrum of adult or non-formal education, the challenge may be no less comprehensive. Such education should reach:

- adults completing their school education

- students registered for certificated and non-certificated correspondence or evening/part-time courses

- people attending general interest programmes

- participants at public debates, community seminars/workshops and action-orientated training sessions

- TV viewers

Whilst economics is only one of the many courses offered in these programmes and may therefore not seem to be in need of special efforts by those usually involved in the more advanced (academic) teaching of the subject, it is a fact that the subject matter of economics - also in these programmes - has become more controversial and is so closely related to the full complexity of South Africa's current socio-economic and socio-political changes that it demands more explicit attention. Taking a passive attitude vis-á-vis those programmes raises the danger that grossly oversimplified 'courses' - erring either towards the left or the status quo - are offered to relatively large and often quite influential audiences. Even a cursory glance at the level and content of contemporary debate in South Africa about issues like

- unemployment and unemployment insurance

- inflation

- import control

- rural poverty and development

- the informal sector and how it might expand

- taxation and tax reform

- price and rent controls

- insurance policies and social pensions

- HP's and consumer protection

- wage levels and wage differentiation

- affirmative action and discrimination

- income and wealth inequalities

- foreign investment versus disinvestment

- land ownership system

- nationalization and state enterprises

and many other 'topical' issues, should make the need for the serious involvement of informed and broadminded academics perfectly clear. With the ideological 'battle' about South Africa's future socio-economic system escalating, objective, yet sympathetic and committed 'adult education' becomes vital - with the search for effective methods of spreading such education having only just started. What we need is not the SABC/SATV type of ideological brainwashing aimed at some simplistic 'free enterprise' ideology, but grassroots-orientated adult education about the facts, forces, conflicts, potentialities and constraints of our economy and the scope for adjustment, reform, reorganization or alternative structuring.

It falls outside the scope of this article to suggest who should get engaged in this field or how. It should be sufficient to have raised the issue and to express interest in any efforts already in process at present.

\section{Conclusion: The task ahead}

As suggested in the introduction, this article has only been exploratory in a field that seems highly neglected amongst academic economists in South Africa, but a field that demands increasing attention.

One of the first steps in the direction of more constructive contributions in this field may be the recognition among academics that the field of 'economics teaching' as outlined in this article is as 'relevant' as the more conventional subdisciplines and demands the same attention and 'rewards', As a second closely related step one would hope for some en couragement for research or publication in this field amongs those in control of the (South African) economic journal literature. Thirdly, one would expect that the HSRC and other bodies would support research in this field, even though the content may be less 'theoretical' than conventional economic research. This might apply in particular to explorative curriculum research and the design of alternative texts, bearing in mind the very important fact that school textbook publishers are - for good business economic reasons - exceedingly 'conservative' in their approach to the content and approach of newly competing texts.

As a fourth step in a broad-based strategy educational authorities (in this subject area) and teaching research orientared academics covering all educational segments and universities should enter a more permanent dialogue about the need and scope for curriculum reform, teaching methods, training and the production of appropriate teaching material. Such dialogue might trigger off further efforts in these respective directions, with particular attention then given to the specific educational needs - if any - of the different school groups.

Parallel to these initiatives one would hope that interest about reform needs and possibilities at undergraduate study level would also increase and eventually lead to concrete action. Work on a concerted, inter-university basis for a Southern African orientated introductory text could be a symptom of such efforts, though it may eventually not even materialize, given academic individualism, campus jealousy and other inhibiting factors. Oddly enough, it may be easier to mobilize such a project for Afrikaans-speaking students than for the larger number of (black and white) Englishspeaking students. Yet, with some sense for originality and innovativeness we may at least succeed in the preparation of appropriate empirical support material - other than what is regularly 'pirate-copied' at the more liberal campuses.

Finally, the adult-education teaching field also demands deliberate action, although an appropriate strategy may be even more difficult to pursue, given the diversity of needs and the unpredictability of effective market demands. Here again progress will to a large extent depend on concerted action between different training agencies and those willing to prepare material.

In conclusion, some comments - though controversial in the light of free market principles - seem relevant with respect to the commercial production of economics 'text' in South Africa. The scarcity of good material and the inappropriateness of much of the financially profitable material has already been commented upon. In order to succeed in future, conventional practices may have to be adjusted in several directions: - publishers and users may have to swallow some of their pride by getting used to really 'low-cost' productions;

- authors may have to limit some of their individualism and cooperate more closely with co-authors at a wider range of institutions;

- teaching staff may have to accept some limitations in their choice of published material;

- all the parties concerned should seriously consider 'cooperative publication ventures' as has become more commonplace in Europe and other countries with limited local markets for academic books;

- more attention should be given to the low cost reproduction 
of collections of articles, chapters, excerpts, etc., with adherence to (flexibly interpreted) copyright rules - and, if possible, with the cooperation of openminded publishers; - private enterprises should be encouraged to sponsor (or cooperate in the preparation of) local teaching material (without unduly interfering in the content) - a good example being the material produced by some of the banks, which might easily be reproduced at low cost for larger student numbers.

We may find further useful hints about new possibilities if we closely monitor steps taken in other Third World countries, some of whom have taken up these challenges long before we seem to get moving.

\section{Notes}

1. From South African economics didactics courses we have only been able to trace one local source, viz. Eksteen 1975. In this booklet of $193 \mathrm{pp} ., 45$ pages cover 'Besondere didaktiek van Ekonomie', with the bibliography including two items of local origin, though both of little direct relevance. On an even more practical level see Burger (1978a: 194 - 197; 1978b: 231 -234). From a perusal of the college/technikon/University exam papers it seems clear that the only subject matter directly related to South African Economics, which is covered in those courses is the content of the syllabus.

2. Virtually the only recent article in the $S A J E$ is that of Zarenda, $\&$ Rees, 1984: $188-207$. They also refer to the inaugural lectures of proff. D.J.J. Botha (1973) and M.L. Truu (1974) which covered aspects of the training of economists (see Botha, 1973: $281-290$ ).

3. For the contemporary US literature see in particular the articles in the Journal of Economic Education, which was started in 1969. For a more dated and critical 'classic' on the topic see Robbins, 1955: 579-593, and for a review see Siegfried \& Fels, 1979: $923-939$.

4. Within the US context see Sherman, 1984: $265-274$.

5. For more details see the project outline, Links \& Thomas, 1985.

6. A first workshop was planned for September 1985, but had to be postponed till 1986 due to the school disruptions.

7. English language (open) universities concentrate on special 'Academic Support Programmes', whereas black universities usually incorporate those elements into their mainstream teaching. Afrikaans language universities do not seem to have been active in this field as yet. For a novel approach to 'bridging' study years as well as curriculum reform see the preparatory work done for SACHED's Khanya College, which also offers a first year course in Economics (starting 1986 in Cape Town and Johannesburg).

8. Employers of 'economics major' graduates advance little by way of feedback on expected or experienced know-how of their recruits; yet, it is known that many employers are rather critical about conventional academic syllabi.

9. Compare, for example, a staff of about 20 post-honours academics for approximately 1500 students at UCT's School of Economics, with 5,5 for 700 at UWC (in 1985).

10. For the US/UK situation in the 1970s see Lumsden (1970) and Lumsden, Attiyeh \& Scott, 1980; for a European overview see Roper, 1970 and with respect to Africa see Livingstone, 1973.

11. This seems close to the approach taken by Botha $(1981 ; 1985)$

12. As an example of the type of literature available to West European undergraduate students see Hummel, 1984.

13. For examples of such alternatives see (i.a.) Robinson \& Eatwell (1973), Aboyade (1983), and Routh (1984).

14. The total exclusion of economic history modules, which has become widespread at English language universities (where seperate Economic History departments became established) seems even more deplorable.

15. Over the years only four basic texts written in Afrikaans have reached broader acceptance, viz. Schumann, Franzsen \& de Kock, Ekonomie - 'n Inleidende Studie (last revised edition appeared in 1964), Lombard, Stadler \& Van der Merwe, Die Ekonomiese Stelsel van Suid-Afrika (the latest revised edition (1985) excludes P.J. van der Merwe and includes P.J. Haasbroek as co-author), van den Bogaerde's UNISA based texts in Micro and Macro economics and Stapelberg \& Steyn (1983).
16. Nattrass, 1982 (this replaces the 'classic' with the same title by Prof. D.H. Houghton).

17. New books currently under consideration or in production include Matthews; du Plessis; and Terreblanche, whereas a long expected text by Botha and Zarenda (Wits) does not seem to materialize.

18. For example at the University of Transkei Afrikaans language material is virtually inaccessible to students and the cost as well as the style of foreign texts makes most of them difficult to be used.

19. Internationally, the situation seems substantially different. See e.g. Lumsden (1970) and, with respect to a topic like computerized education in economics, the contributions at the 1984 conference of the American Economic Association. For a broader, most useful overview also see Bach \& Kelley, 1984: $12-18$.

20. The following list includes all the Technikons:

1. Academy of Tertiary Education, Windhoek

2. Cape Technikon, Cape Town

3. Mangosuthu Technikon, Jacobs/Natal

4. ML Sultan Technikon, Durban

5. Natal Technikon, Durban

6. Northern Transvaal Technikon, Soshanguve

7. OFS Technikon, Bloemfontein

8. Peninsula Technikon, Belville

9. Port Elizabeth Technikon, PE

10. Pretoria Technikon, Pretoria

11. RSA Technikon, Braamfontein

12. Vaal Triangle Technikon, Vanderbijlpark

13. Witwatersrand Technikon, Johannesburg

21. The following excerpt from a technikon's response to a questionnaire about literature may illustrate the point:

'It is pertinent to point out that this Technikon has difficulty in understanding the phrase "technikon-level students". There is no special "level" specifically for technikons - our courses are on the same level as those of the universities. The only modicum of difference could be that the emphasis at technikons is of a practical nature.'

22. This is apparently the case between UWC and the Peninsula Technikon, due to more stringent accommodation constraints at the latter institution.

23. E.g., the envisaged adaptation of Lobley (1983).

24. This inherent dichotomy has received further impetus at the English language universities, where opposition to military service and concern about future political instability in South Africa may have orientated relatively more graduate students towards further studies (and/or their career) overseas.

25. Only recently a well-known Cape industrialist expressed his disillusionment about the reaction of a university academic when approached about research on the problems and porential of specific economic sectors ('This is not University-type research; approach one of the Technikons ....').

26. The lists regularly released in the HSRC Research Bulletins contain too little information.

27. For an international (mainly UK) perspective on the topic see Lee, 1980 which contains further useful references and also Henderson, 1980 and Burkhardt, 1976. About the role of Universities, see Bach (1961: $579-586)$.

28. A recent UCT MA (Psychology) graduate, who worked on 'Alternative Education', summed up the key objections to the present systems as follow's:

- authoritarian structures in schools, and the total lack of participation of students in the teaching-learning process;

- lack of exposure to other views and experiences;

- 'uselessness' of certain subjects

- (pupils') perception that the schooling system was an extension of the apartheid system. (Weekend Argus, 1985:9)

29. Cf. Department of Education (Prov. Admin. of the Cape of Good Hope), Senior Secondary Course: Syllabus for Economics.

30. Swanepoel \& Stassen, Economics for Standard 8; Economics for Standard 9; (and) Economics for Standard 10. More recent books include a set by M. Levin and C.R. Wait (Vista/UPE).

31. For those opposed to local journals, the UK-produced monthly 'African Business', readily available in South Africa, might be an interesting alternative.

\section{References}

Aboyade, O. 19\%3. Integrated Economics: A study of Developing Economies. Addison-Wesley. 
American Economic Association Papers. 1970. vol.60/2, 352.

American Economic Association. May 1985. Papers and Proc., $80-96$.

Bach, G.L. May 1961. Economics in High Schools - The Responsibility of the Profession. AEA, vol.51/2, 579-586.

Bach, G.L. \& Kelley, A.C. May 1984. Inproving the Teaching of Economics: Achievements and Aspirations. AEA Papers and Proc. vol.74/2, $12-18$.

Botha, D.J.J. September 1973. A School of Economic Studies. $S A J E$, vol.41/3, $281-290$.

Botha, D.J.J. June 1981. The Image of the Academic in South Africa. Department of Economics, University of the Witwatersrand, Occ. Paper No.2.

Botha, D.J.J. Winter 1985. Die Degradering van ons Universiteit. Die Suid-Afrikaan.

Burger, S.J. 1978a. Die Praktiese Aanbieding van Ekonomie Die Unie, November; $194-197$.

Burger, S.J. 1978b. Die Praktiese Aanbieding van Ekonomie. Die Unie, Desember, $231-234$.

Burkhardt, G.A. 1976. Teaching Economics in the Secondary School (Australia). McGraw.

Coleman, F.L. (ed) 1983. Economic History of South Africa. HAUM.

Du Plessis, S.P.J. International Economics. Pretoria: Academica

Eksteen, F.R.L.N. 1975. Die Didaktiek van die Ekonomiese Wetenskappe. Nasou, $193 \mathrm{pp}$.

Franzsen, D.G. (ed). 1984. Owerheidsfinansies in Suid-Afrika. Butterworth.

Goedhuys, D.W. 1982. Money and Banking. McGraw-Hill.

Griffiths, H.R. \& Jones, R.A. 1980. South African Labour Economics. McGraw-Hill.

Henderson, W. 1980. Teaching Economics in African Secondary Schools. Heinemann.

Hummel, T.R. (ed). 1984. Das Studium der Wirtschaftswissenschaften: Einführung und Orientierungshilfe Campus Studium, Frankfurt.

Kantor, B.\& Rees, D. 1982. South African Economic Issues. Jutas. Lee, N. (ed). 1980. Teaching Economics. 3rd Edition. Heinemann. Links, E. \& Thomas, W.H. May 1985. Secondary and Tertiary Economic Education Project (STEEP) - Project Proposal. University of the Western Cape.
Livingstone, I. (ed). 1973. The Teaching of Economics in Africa. Sussex University Press.

Lobley, D. 1983. Success in Economics. 2nd Edition, J. Murray.

Lombard, Stadler \& Haasbroek. 1985. Die Ekonomiese Stelsel in Suid-Afrika.

Lumsden, K.G. 1970. Recent Research in Economics Education. Prentice Hall.

Lumsden, K.G., Altiyeh \& Scott. 1980. Economics Education in the UK. Heinemann.

Matthews, J. (ed). 1983. South Africa in the World Economy. McGraw Hill.

Matthews, J. International Economic Relations and Organisations. Durban: Macmillan.

McCarthy, C. 1983. Monetary Economics - A South African Perspective. HAUM.

Nattrass, J. 1981. The South African Economy. OUP.

Nedbank. 1983. South Africa - an appraisal. 2nd Edition.

Robbins, L.C. Dec. 1955. The Teaching of Economics in Schools and Universities. Econ. J., vol.65/260, $579-593$.

Robinson, Joan \& Eatwell, J. 1973. An Introduction to Modern Economics. McGraw.

Roper, J.F.H. 1970. The Teaching of Economics at University Level. G.G. Harrap.

Routh, G. Economics: An Alternative Text. Macmillan

Schumann, Franzen \& de Kock. 1964. Ekonomie - 'n Inleidende Studie.

Sherman, H.J. 1984. Contemporary Radical Economics. J. Econ. Educ., vol. 15/4, $265-274$.

Siegfried, J.J. \& Fels, R. Sept. 1979. Research on Teaching College Economics - A Survey. J. Econ. Lit., vol. 17/3, $923-939$.

Stapelberg \& Steyn. 1983. Ekonomie - 'n Inleidende Studie. NHS.

Swanepoel, D.J. \& Stassen, D.F. Economics for Standard 8; Economics for Standard 9; and Economics for Siandard 10.

Terreblanche, S.J. Politieke Ekonomie en Welvaart. Academica.

Weekend Argus. 1985, October 12, 9.

Zarenda, H. \& Rees, D. June 1984. Economics Education in South Africa - An Output Analysis. $S A J E$, vol. 52/2, $188-207$. 